\title{
Rememoração e retrotopia: Folha de S. Paulo e O Globo na cobertura dos 55 anos do golpe de 1964
}

\author{
Fernanda Nalon Sanglard ${ }^{1}$ (i) \\ Lucia Santa Cruz ${ }^{2}$ \\ Juliana Gagliardi ${ }^{3}$
}

\begin{abstract}
Este artigo analisa como dois dos principais veículos da grande imprensa brasileira, O Globo e Folha de S. Paulo, abordaram o aniversário de 55 anos do golpe civilmilitar de 1964. Parte-se de referencial teórico sobre memória e nostalgia e da análise de conteúdo aplicada às narrativas jornalísticas publicadas entre 26 de março e 2 de abril de 2019 para responder às seguintes questões: Houve nostalgia nas narrativas de atores políticos em relação à ditadura? Como as narrativas jornalísticas abordaram esse sentimento e se posicionaram sobre isso? Os resultados indicam a existência de memórias em disputa referentes à ditadura, o que se evidencia na fala de diversos atores. Muito embora os veículos não se alinhem com o sentimento nostálgico, a retrotopia foi identificada em $45 \%$ das declarações das fontes e o presidente Jair Bolsonaro foi o principal personagem dos textos jornalísticos.
\end{abstract}

Palavras-chave: nostalgia; Golpe de 1964; jornalismo; O Globo; Folha de S. Paulo

\section{Introdução}

Efemérides são um dos critérios de noticiabilidade pelos quais os veículos jornalísticos se orientam na seleção e ordenação dos fatos ${ }^{4}$. A data específica de aniversário pode justificar o motivo de se noticiar um acontecimento que já teve lugar no passado, e que não seria, portanto, exatamente atual. "É a efeméride - o próprio tempo é utilizado como esse gancho" (Traquina, 2008, p. 81). Datas comemorativas ou de rememoração, consequentemente, sempre renderam pautas em veículos jornalísticos. Toda redação mantém uma lista de datas e efemérides que podem funcionar como ganchos para reportagens do dia a dia ou para os especiais de final de semana.

\footnotetext{
1 Pontifícia Universidade Católica de Minas Gerais (PUC Minas), Programa de Pós-Graduação em Comunicação Social (PPGCOM). Belo Horizonte (MG), Brasil. E-mail: <nandanalon@yahoo.com.br>.

2 Escola Superior de Propaganda e Marketing (ESPM) - Rio. Rio de Janeiro (RJ), Brasil. E-mail: <lucia.santacruz@espm.br>.

3 Universidade Federal Fluminense (UFF), Laboratório de Mídia e Democracia (Lamide). Niterói (RJ), Brasil. E-mail: <jugagliardi@gmail.com>.

4 Critérios de noticiabilidade são características que veículos jornalísticos observam quando vão selecionar que acontecimentos podem virar notícias (Galtung e Ruge, 2016; Traquina, 2005; Wolf, 1999). Wolf considera que os valores-notícia agem em todo o processo de produção jornalística (seleção de acontecimentos e elaboração da notícia), no entanto, com importância diferente em cada etapa do trabalho.
} 
Os aniversários do golpe civil-militar ${ }^{5}$ de 1964 começaram a ser cobertos jornalisticamente ainda durante a ditadura militar, quando as solenidades anuais conformaram um ritual político que foi noticiado pela imprensa anualmente (Gagliardi, 2014). Posteriormente, ao fim da ditadura, com base no valor-notícia da efeméride, os veículos continuaram pautando a data, ainda que com ênfases e motivações diferentes ao longo do tempo.

O golpe já havia sido objeto de ampla cobertura midiática no seu cinquentenário, em 2014. Ao analisar 8.422 narrativas jornalísticas sobre a ditadura publicadas entre 2012 e 2014 por mais de 60 veículos de comunicação, Sanglard (2017b) identificou que o ápice dessa cobertura (15\% do total) se deu justamente entre março e abril de 2014, em decorrência dos 50 anos do golpe. Os principais jornais brasileiros, em suas versões impressas e online, os sites informativos, as revistas semanais e as emissoras de televisão editaram especiais, com reportagens e longform, infográficos, vídeos, linhas do tempo.

Cinco anos mais tarde, novamente, a efeméride pauta o noticiário. Há, porém, um cenário bastante diverso do encontrado na época do cinquentenário. Enquanto em 2014 o governo liderava um movimento de reconhecimento e de reparação dos crimes cometidos pelo Estado durante o período ditatorial, em 2019 presenciamos a negação por autoridades políticas da própria existência de uma ditadura.

Em 2014, não só havia um consenso público de que o golpe de 1964 culminara em um regime ditatorial no Brasil, como estavam em curso as investigações da Comissão Nacional da Verdade (CNV), instituída em 2012 pela então presidente da República, Dilma Rousseff, com o objetivo de investigar os crimes de Estado como ação em prol da "memória e verdade" (Sanglard, 2017b).

Já em 2019, o presidente Jair Bolsonaro, menos de três meses após assumir o cargo, determinou que os quartéis deveriam celebrar devidamente a data (Fernandes e Uribe, 2019). Na mesma semana, declarou que a intenção da sua determinação era "rememorar" o fato e identificar pontos corretos e errados para o "bem do Brasil no futuro" (Mazui e Barbieri, 2019). Seis dias mais tarde, o Palácio do Planalto divulgou por WhatsApp 6 um vídeo negando que um golpe de Estado teria instaurado a ditadura militar no Brasil $(\mathrm{G1}, 2019 \mathrm{~b})$. O vídeo 7 foi reproduzido também no perfil do Twitter do deputado federal Eduardo Bolsonaro (PSL-SP), filho do presidente.

\footnotetext{
5 Neste artigo, optamos por nomear de golpe "civil-militar" o processo de articulação política entre civis e militares que levou à deposição do presidente João Goulart e à tomada do poder pelos militares em 1964, resultando em uma ditadura, que se manteve por 21 anos. Optamos pelo termo "ditadura militar" porque, apesar de também ter havido apoio civil ao regime, ele foi comandado exclusivamente pelo alto escalão das Forças Armadas - todos os presidentes eleitos indiretamente eram militares de alta patente - e a estrutura do governo foi militarizada, tendo sido cassados até mesmo alguns dos atores políticos civis que haviam apoiado o golpe. Isso não quer dizer que desconsideramos o apoio de setores civis ao regime autoritário em toda a sua duração, mas reforça a intenção de demarcar a militarização do processo repressivo. Para mais informações e discussões sobre as nomenclaturas, ver: Fico (2014) e Sanglard (2017a).

${ }^{6} \mathrm{Em}$ lista de transmissão destinada a jornalistas.

7 A produção audiovisual em questão teria sido financiada pelo empresário Osmar Stábile, ex-vice-presidente do time de futebol Corinthians (Folha de S. Paulo, 2019).
} 
Nesse quadro que parece apontar para uma ressignificação do movimento, a proposta deste artigo é refletir sobre como a ditadura, à qual o Brasil se viu submetido entre 1964 e 1985, vem sendo abordada pela imprensa brasileira e por seus principais atores políticos 55 anos depois do golpe civil-militar.

Para tal, analisamos as narrativas jornalísticas publicadas na ocasião desse aniversário em dois dos principais jornais brasileiros: O Globo e Folha de S. Paulo. O objetivo é verificar como esses dois veículos da grande imprensa abordaram a data a partir, especialmente, do posicionamento do governo. Tomamos como hipótese que esses discursos estavam impregnados do sentimento da nostalgia, diferindo, nesse sentido, das declarações consideradas pela mídia cinco anos antes. Com base no referencial teórico sobre memória e nostalgia, pretende-se entender como, em um Estado que se diz democrático, a ditadura é trazida ao presente, ressignificada e até mesmo considerada como opção viável a partir do discurso de autoridades políticas. Utilizamos, como método, a análise de conteúdo (Krippendorff, 1990; Bardin, 2008) aplicada às narrativas jornalísticas publicadas pelos dois veículos no período entre 26 de março e 2 de abril de 2019.

O artigo é dividido em seis seções: "Memória e nostalgia", em que apresentamos os conceitos que inspiraram este estudo; "Memória social e política", em que propomos uma breve discussão acerca das disputas que envolvem o conceito de memória social; "Passado e presente: comemorando a ditadura", em que contextualizamos o histórico das "comemorações" e rememorações do golpe noticiadas pelos jornais; além de duas seções analíticas - "O Globo, Folha e o aniversário do golpe em 2019" e "Análise qualitativa do corpus" - e as "Considerações finais".

\section{Memória e nostalgia}

Se as efemérides são um recurso de que o jornalismo se vale para identificar que acontecimentos podem ser transformados em notícias, também é legítimo afirmar que as datas históricas e comemorativas se constituem em gatilhos para que o passado seja revolvido e se faça presente como um terreno de disputa de narrativas.

Conforme Jelin (2017), a rememoração e o "memorável" surgem quando as rotinas aprendidas e repetidas, ou seja, aquilo que se tornou habitual, se rompem e se transformam em uma narrativa que se vincula a algum objeto ou imagem, podendo, portanto, converter-se em algo comunicável.

Halbwachs (1990) dizia ser impossível conceber o problema da evocação e da localização das lembranças sem tomar como ponto de aplicação os quadros sociais reais que servem de referência nessa reconstrução que chamamos de memória.

Essa frase nos indica que a memória é formada por camadas de lembrança e esquecimento, como Pollak $(1989,1992)$ irá ressaltar, apontando também para a sua vinculação a um contexto histórico e social. "Na verdade, a memória não é o passado, senão a maneira como os sujeitos constroem um sentido do passado, um passado que se 
atualiza em seu enlace com o presente e também com um futuro desejado no ato de rememorar, esquecer e silenciar" (Jelin, 2017, p. 135, tradução nossa).

Lembrar é um exercício que acontece no presente, o que significa que o passado não aconteceu: ele acontece a cada vez que se evoca o que passou. Portanto, é na recuperação - e na narração - desse passado que este se faz acontecimento e se manifesta de maneira palpável para a sociedade. Essa reconstrução não é homogênea, mas se dá num terreno impregnado de disputas, porque a versão que se torna oficial se cristaliza como histórica, numa aproximação intencional com o conceito de verdade. Conforme Jelin (2017), o que o passado deixa são traços, rastros. Mas esses traços não constituem memória, a menos que sejam evocados e colocados em uma estrutura que lhes dê significado.

Nessa recuperação do já vivido, identifica-se cada vez mais o sentimento nostálgico, tanto como uma saudade pelo que se perdeu quanto como um desejo de restauração daquela situação ideal. Boym (2001) distingue esses dois tipos de nostalgia como reflexiva e restaurativa. Enquanto a reflexiva se fixa na perda e na recuperação dos sentimentos, ligando-se mais a estados individuais da rememoração, a restaurativa pressupõe um retorno ao estado original, sempre concebido como paradisíaco, perfeito, ideal. "Neste sentido, o passado para a nostalgia restaurativa é um valor para o presente; o passado não é uma duração, mas um instantâneo perfeito (...) e não deve revelar nenhum sinal de decadência; deve ser tinta fresca na sua imagem original e manter-se eternamente jovem" (Boym, 2001, p. 49).

Nostalgia é a "doença" da distância temporal e da desterritorialização. A nostalgia restaurativa assume os dois sintomas. A distância é compensada pela experiência íntima e pela presença do objeto desejado. A desterritorialização é curada por um retorno à casa, preferencialmente uma casa coletiva. Não há problema se não é exatamente sua casa; quando você chegar lá, você terá esquecido a diferença (Boym, 2001, p. 44).

Niemeyer, que defende que a nostalgia possui uma pluralidade de formas, expressões e significados, também segue nessa mesma linha, advertindo que o sentimento tem sido associado à melancolia, saudade ou homesickness ${ }^{8}$ (doença da ausência da casa).

A nostalgia situa-se entre recordação e esquecimento, idealização e criatividade, é uma lembrança de tempos e lugares que não existem mais, não são mais acessíveis ou talvez nunca tenham sido. (...) O sentimento nostálgico não é meramente voltado para um retorno a um lugar ou tempo passado, mas também abrange outras temporalidades, como o presente e o futuro, e está frequentemente relacionado a imaginações utópicas sociais ou políticas (Niemeyer, 2018 p. 29).

\footnotetext{
${ }^{8}$ Apesar de homesickness ser traduzida por vezes como saudade, aqui Niemeyer usa num sentido específico, que remonta à acepção inicial da palavra nostalgia, quando cunhada no século XVII, para designar uma doença que acometia soldados suíços que estavam longe de sua terra natal.
} 
A perspectiva utópica está presente também no conceito de retrotopia, apresentado por Bauman (2017). Para ele, retrotopia é a utopia do passado - já que não consegue imaginar futuros pois perdeu o horizonte utópico, a humanidade se volta para uma glorificação de práticas e projetos de tempos passados. Nesse processo, a nostalgia se instala como um mecanismo de defesa e de idealização de um passado mitificado, que nunca existiu realmente e do qual são pinçadas algumas partes, selecionadas para compor uma versão mais adequada às demandas individuais ou de alguns grupos.

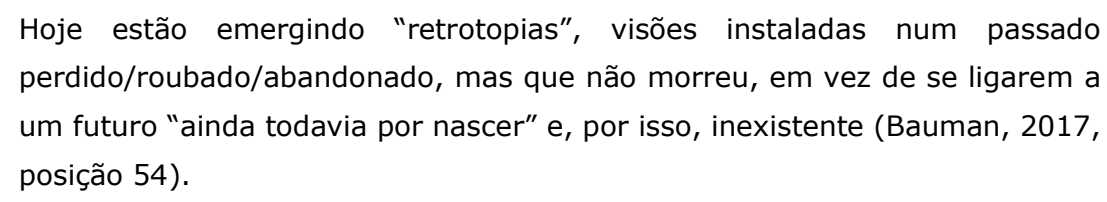
perdido/roubado/abandonado, mas que não morreu, em vez de se ligarem a um futuro "ainda todavia por nascer" e, por isso, inexistente (Bauman, 2017, posição 54$)$.

Para o autor, uma acomodação da consciência e um esquecimento de velhos medos levou a mentalidade pública a mudar radicalmente:

(...) em lugar de investir as esperanças públicas de melhoria num futuro incerto e "sempre obviamente duvidoso demais", reinvesti-las mais uma vez no passado vagamente relembrado, valorizado por sua suposta estabilidade e, portanto, confiabilidade (Bauman, 2017, posição 91).

Uma vez despojada do poder de modelar o futuro, a política tende a ser transferida para o espaço da memória social - um espaço imensamente mais suscetível a manipulações e administração, e, por isso, promissor de uma chance de bem-aventurada onipotência, há muito perdida (e talvez irrecuperável) no presente e no futuro próximo. Especialmente quando essa recuperação memorial se dá pelo acionamento da nostalgia, por esse desejo de restauração, de reconstrução.

O perigo disso advém do fato de que, como Grainge (2000, apud Santa Cruz e Ferraz, 2018) ressalta, "a nostalgia ancora-se no tempo presente, de onde parte em forma de narrativas, estilos e ações, [refletindo] novos modos de engajamento com o passado" (p. 7). Esses novos modos de engajamento com o passado, por sua vez, podem se aproximar do que Appadurai (2011) vai chamar de "nostalgia sem memória" ou "nostalgia imaginada", quando grupos desejam um passado que não experienciaram, mas que se reveste de tamanha idealização que se torna o tempo mítico ao qual esses grupos aspiram. O passado se converte, assim, numa alternativa ao presente e, muitas vezes, na única alternativa desejável ao presente. Como Bauman (2017) reforça, a retrotopia é uma visão seletiva, passivamente e obedientemente suscetível de manipulação.

Entre os novos modos de engajamento com o passado, podemos citar o governo do atual presidente da República, Jair Bolsonaro, que frequentemente promove um estímulo formal ao sentimento nostálgico, seja diretamente ou por intermédio de seus ministros e assessores. Chama a atenção o poder que um líder de nação possui em estabelecer pautas dessa natureza. Em diversas declarações, ainda como deputado 
federal ${ }^{9}$, ou já na presidência, Bolsonaro faz referência aos "bons tempos" da ditadura militar, capitaneando esse apelo à nostalgia como um estado desejável por parte da população.

\section{Memória social e política}

As discussões sobre a rememoração do golpe de 1964 e, consequentemente, da ditadura apontam para a necessidade de refletir sobre as noções de memória coletiva e memória social e pública, considerando o modo como são abordadas academicamente e adotadas pelo Estado brasileiro.

Tido como o expoente da teorização sobre "memória coletiva", Halbwachs (1990) propõe a ideia de sobreposição de memórias dos indivíduos e de comunidades amplas (como família e nação) para demonstrar que elas dependem de estruturas sociais. Ele enfatiza a natureza recursiva da memória individual e coletiva - uma sempre habitando a outra. Segundo Halbwachs, os indivíduos podem se lembrar de eventos cronologicamente e espacialmente, mas, em geral, lembrar-se-ão em termos de conectividade, já que, como ser social, a pessoa vivencia os eventos em sua relação com outras pessoas. Desse modo, a sociedade é responsável por definir o que é memorável e onde essa memória será preservada, não existindo, portanto, memória individual que não seja também coletiva, por estar permeada pela relação com o outro.

Pollak (1992) propõe avanços ao considerar a dimensão política desse processo. $\mathrm{O}$ autor recorre às datas comemorativas e festas nacionais para demonstrar como as memórias são estruturadas do ponto de vista político: "A memória organizadíssima, que é a memória nacional, constitui um objeto de disputa importante, e são comuns os conflitos para determinar que datas e que acontecimentos vão ser gravados na memória de um povo" (p. 204).

Todavia, segundo Oliveira (2017), durante muito tempo estudiosos adotaram a noção de memória coletiva de modo pouco crítico, tendo restado a poucos autores, entre eles Jelin $(2002,2017)$, a tarefa de problematizar tal conceituação. Jelin ressalta que o conceito de memória coletiva está relacionado a uma memória estável, ainda que não permanente, que congrega o discurso hegemônico encontrado na coletividade. Segundo Jelin (2002, p. 22), memória coletiva se relaciona a "algo com entidade própria, como uma entidade reificada que existe acima e separada dos indivíduos. Essa concepção decorre de uma interpretação durkheimiana extrema (pode se tomar os fatos sociais como coisa)".

É a partir dessa reflexão que Jelin adota as expressões "memória social" e "memória pública" para afirmar não ser possível a existência de apenas uma memória coletiva, visto que as memórias estão sempre em disputa e negociação. Tal disputa se dá muitas vezes no campo da linguagem. Desse modo, a memória pública é constituída pelo

\footnotetext{
${ }^{9}$ Bolsonaro foi deputado federal por sete mandatos antes de ser eleito presidente.
} 
entrelaçamento de tradições e memórias individuais, afetadas pela prerrogativa de algumas vozes não só mais poderosas, mas também com mais acesso às arenas públicas.

É importante considerar nesse enredo que o Brasil optou historicamente por adotar em suas transições - em geral longas e controladas - a postura do apaziguamento focado no apagamento das memórias traumáticas e na manutenção de alguns atores políticos no poder, de modo a tornar as transições pactuadas. Ou seja, não houve propriamente enfrentamento e rupturas significativas, mas sim pactos dos grupos dominantes, que, em nome da ordem e da governabilidade, estabeleceram estratégias de conciliação com o passado baseadas no esquecimento institucionalizado.

Segundo Jelin (2017), como os processos de construção da memória estão sempre abertos e nunca terminados, os atores políticos costumam lançar na esfera pública narrativas sobre o passado e lutar por impor sua versão como dominante. Todavia, essas disputas são constantemente identificadas e questionadas. É também por isso que leis de anistia, comissões da verdade, datas comemorativas e monumentos não representam algo acabado e unívoco, estando sempre passíveis de questionamentos e ressignificações.

Como toda "memória impedida"10, usando o termo adotado por Ricœur (2007), a memória da ditadura é traumática e representa uma ferida, interferindo nos mecanismos de memória e esquecimento, por não ter sido processada. Porém, as tentativas de apagamento público das memórias do golpe e da ditadura parecem surtir o efeito inverso do que desejam aqueles que almejam jogar para debaixo do tapete o que ocorreu: elas retornariam como "recalque", nos termos de Freud, ou ressentimento, conforme Nietzsche. Para essas vertentes teóricas, o passado traumático precisa ser elaborado, passar por processo crítico e de ressignificação para que seja superado e, de certo modo, esquecido ${ }^{11}$.

No Brasil, há indicativos de que o passado autoritário não tenha sido superado (Fico, 2014; Sanglard, 2017b; Schwarcz, 2019). Primeiro, porque não foi algo bem trabalhado socialmente, que tenha sido alvo constante de escrutínio público, aceito e enfrentado pelo Estado. A negação - dos abusos coloniais e dos privilégios das elites, do racismo e da ditadura - é apenas um sintoma desse processo. Segundo, porque não construímos ou investimos em espaços de rememoração desses episódios. Terceiro, porque limitamos a compreensão sobre quem são as vítimas, os afetados e os concernidos nos processos autoritários, fazendo com que setores significativos da sociedade não se considerem ou não sejam considerados atingidos por violações de direitos, ainda que tenham sido.

\footnotetext{
10 A ideia de "memória impedida" de Ricœur tem inspiração nas obras "Luto e melancolia" e "Recordar, impedir e elaborar", de Freud. Essa abordagem sugere que algumas memórias não são processadas, mas sim inconscientemente repetidas. A resistência à lembrança desses traumas se manifesta pela (inconsciente) "compulsão à repetição" e só poderia ser vencida a partir de um trabalho de rememoração, semelhante ao trabalho de luto. Assim, o que Freud chama de superação do trauma, Ricœur apresenta como reconciliação com o passado.

${ }^{11}$ Esquecimento, nesse sentido, ganha conotação positiva e não representa um apagamento de rastros, uma falha humana ou incapacidade, mas sim a potencialidade de construir uma memória capaz de promover um esquecimento salutar, um esquecimento de reserva. Ou seja, as memórias seriam trabalhadas de tal modo que não mais precisariam ser constantemente repetidas, pois ficariam à disposição para ser acionadas quando necessário.
} 
Esse processo explica algumas das razões que levam a ser socialmente aceito o discurso de atores políticos e formadores de opinião que consideram o retorno do autoritarismo, ou até mesmo da ditadura, uma opção viável. Opção nostálgica, ou seja, uma retrotopia, já que seleciona um passado político que não se ancora em fatos reais, mas que é imaginado como uma utopia e, portanto, idealizado por alguns atores, para quem a narrativa produzida é adequada a seus interesses. Esse impulso se dá mesmo após a divulgação de um relatório público, produzido pela CNV por determinação do Estado, que aponta as graves violações de direitos humanos cometidas no regime ditatorial. A democracia, nesse sentido, parece ser algo que pode ser relativizado e que não merece ser defendido. A ditadura, apesar dos males que ocasionou, é vista, sob essa perspectiva, como algo que teria livrado o Brasil de um "mal maior".

\section{Passado e presente: comemorando a ditadura}

Em 1965, as solenidades de comemoração do primeiro ano do golpe reuniram personagens distintos - governo, militares, sociedade civil, Igreja -, apoiadores do regime que consideravam uma "revolução", e receberam ampla cobertura. Ordens do dia lidas pelos ministros militares, missas, participação do presidente da República. A partir de então os eventos se tornaram regulares, repetindo-se anualmente em diversos estados e em diferentes escalas, e configurando um ritual político em tempos autoritários que a imprensa transformou em notícia. Tratava-se de uma ocasião privilegiada em que o governo falava de si. Essa dimensão simbólica uniu dois discursos - um sobre o regime (os militares enquanto governo) e outro sobre a instituição militar - e foi uma alternativa para que os militares criassem legitimidade para o regime, a partir, por exemplo, de discursos que enfatizavam coesão e democracia, uma vez que a ditadura nunca foi assumida como tal.

Do ponto de vista jornalístico, na cobertura das "comemorações" da data ocorridas ainda durante a ditadura, a voz do jornalista ocupou espaço reduzido - a reprodução na íntegra dos discursos dos presidentes e dos ministros militares e a descrição dos eventos, embora, no caso de $O$ Globo, sempre acompanhadas de editoriais que defendiam o movimento militar (Gagliardi, 2014). Na cobertura, a imprensa assumiu por algum tempo a função de anais, embora ainda assim estivesse fornecendo visões de mundo (Schudson, 1993). No espaço editorial, o golpe era anualmente festejado na voz do jornal, que bradava que este teria salvado o Brasil de uma suposta ameaça comunista personificada em João Goulart ${ }^{12}$.

Além desses espaços, dos editoriais, da publicação de discursos e das notícias factuais, houve outros como citação de falas oficiais (de forma recortada) e entrevistas (respostas dos presidentes a perguntas enviadas com antecedência por jornalistas), conforme categorias sugeridas por Gagliardi (2014), que também apontavam para a

\footnotetext{
12 Um dos diversos exemplos é o editorial de $O$ Globo, em 1/4/1969, publicado na primeira página do jornal.
} 
reprodução de falas do governo. No final dos anos 1970, há uma mudança na cobertura realizada por $O$ Globo, que passa a apresentar mais matérias interpretativas, reforçando a posição dos jornalistas enquanto analistas do mundo político (Schudson, 1993).

Nos anos 1980, após o fim da ditadura, o espaço dedicado ao evento diminuiu, mas as cerimônias comemorativas continuaram a ser cobertas. Só então se passa a mencionar a repressão, as mortes sob tortura e a Lei da Anistia (Lei n 6.683, de 28 de agosto de 1979). Na década seguinte, a cobertura perde ainda mais espaço e, em alguns anos, a efeméride não é sequer mencionada, mas, ainda assim, o jornal $O$ Globo continua não empregando os termos golpe e ditadura (Gagliardi e Sanglard, 2015). Nos anos 2000, com exceção dos 40 anos, em 2004, a ditadura continuou como um tópico pouco discutido na imprensa.

Cabe aqui relembrar que em 2009, num editorial sobre o referendo que possibilitou reeleição ilimitada ao então governante da Venezuela, Hugo Chávez, a Folha criou um neologismo - ditabranda - para qualificar a ditadura brasileira como branda, se comparada a outras da América Latina no período. Ao editorial, seguiram-se críticas dos leitores e da blogosfera. "A maior parte desse conteúdo enfatiza o papel do jornal como colaborador do regime. O termo foi recebido pelos críticos como uma tentativa de relativizar a história, que o jornal estaria tentando camuflar, esquecer e apagar" (Dias, 2014, p. 13). É possível conjecturar que parte da ampliação da cobertura da Folha quanto às questões envolvendo a ditadura militar tem como base um esforço para anular o mal-estar impingido por esse infeliz neologismo.

Uma considerável mudança acontece no início da década seguinte. Em 2011, no primeiro ano de governo de Dilma Rousseff, o então ministro da Defesa, Nelson Jobim, determinou às três Forças que não houvesse qualquer ato exaltando a data. Nesse contexto, o então comandante do Exército, Enzo Peri, determinou que fosse cancelada a palestra que o general Augusto Heleno, então diretor do Departamento de Ciência e Tecnologia do Exército, faria sobre a "contrarrevolução que salvou o Brasil". Vinte e seis anos depois a efeméride continuava sendo notícia, mas com a novidade de um general ter sido proibido de comemorá-la. Em $O$ Globo, a ênfase dada ao caso recaiu não sobre os crimes da ditadura, mas sobre a questão hierárquica - o verbo calar e sua aplicação a um general (Maltchik, 2011; Éboli, 2011). Agora a disputa pela memória sobressai.

Com a instalação da CNV em 2012 e seus dois anos e sete meses de atuação, a temática começa a ser mais recorrente nos jornais brasileiros, e não apenas nas efemérides, tendo seu ápice em 2014. A "comemoração" do 31 de março também foi se tornando um evento restrito aos militares da reserva do Clube Militar. Os termos golpe e ditadura se consolidam majoritários na cobertura dos aniversários, indicando um posicionamento editorial que prefere as terminologias acusatórias às amenizadoras ${ }^{13}$.

Todavia, apenas em 2013, quase 50 anos depois, O Globo pede desculpas pelo

\footnotetext{
${ }^{13}$ A exceção nesse caso é O Estado de S. Paulo, que não fez na ocasião a mesma revisão sobre o apoio ao golpe de 64 e cujos editoriais ainda utilizam termos amenizadores, como "movimento civil-militar", para se referir ao episódio (para mais, ver Sanglard, 2017a).
} 
apoio que deu aos militares em 1964. Em 30 de março de 2014, foi a vez de a Folha de S. Paulo assumir em editorial que o apoio ao golpe havia sido um erro. Apesar da relevância de tal reconhecimento, o veículo relativizou os danos causados pela ditadura, apontando o crescimento econômico e "outros avanços" para justificar que, à época, o apoio parecia ser a melhor escolha.

Ao analisar o caderno especial "Tudo sobre a Ditadura Militar", publicado pela Folha em decorrência dos 50 anos do golpe, em 2014, Macedo (2018) identifica que esse "tudo" prometido pelo jornal não é algo alcançável e que, mesmo tendo havido ampliação do espaço dedicado à temática e distintos pontos de vista na cobertura, a Folha tenta fazer de sua versão e narrativa a totalidade do que a ditadura representou, tornando invisibilizadas tantas outras perspectivas.

A eleição de Jair Bolsonaro à presidência em 2018 constitui outro marco nessa história. Em polo oposto ao de Dilma, que foi militante torturada durante a ditadura, Bolsonaro é um capitão reformado do Exército e construiu sua popularidade em torno de uma agenda conservadora de ultradireita. Um enérgico apoiador dos episódios de 1964, o presidente considera que não houve ditadura no Brasil, minimiza as consequências da intervenção militar para o processo democrático e é figura historicamente presente nas solenidades comemorativas. Em seu primeiro ano de governo, ao contrário de Dilma, Bolsonaro recomendou que os quartéis celebrassem o 31 de março (G1, 2019a). Com base nessa "novidade", nossa hipótese neste artigo é que houve nesse período a presença de discursos impregnados do sentimento de nostalgia, diferindo-se, nesse sentido, das declarações retratadas pela mídia nos governos anteriores. No tópico a seguir, analisamos a cobertura concedida por $O$ Globo e pela Folha à data, que mais uma vez ganhou expressividade pelo contexto particular.

\section{O Globo, Folha e o aniversário do golpe em 2019}

Com o objetivo de verificar e compreender se o sentimento de nostalgia da ditadura está presente nas narrativas jornalísticas e no discurso dos atores políticos que ganham destaque midiático na data, nesse novo contexto particular, consideramos como material empírico de nossa análise os jornais O Globo e Folha de S. Paulo, dois representantes tradicionais da grande imprensa. A coleta foi realizada extraindo-se materiais publicados no primeiro caderno dos dois veículos, entre 26 de março e 2 de abril de 2019, incluindo o conteúdo noticioso e opinativo. Tal recorte resultou em corpus com 69 narrativas jornalísticas.

A escolha de $O$ Globo e Folha de $S$. Paulo se justifica por serem dois periódicos de circulação nacional, estarem entre os de maior circulação, conforme o Instituto Verificador de Comunicação (IVC), e terem sede em cidades distintas, Rio de Janeiro e São Paulo, respectivamente. O recorte temporal contempla uma semana de cobertura, considerando os dias imediatamente anteriores e posteriores à data de aniversário do golpe de 64 , indo de 26 de março a 2 de abril. 
O método da análise de conteúdo (Krippendorff, 1990; Bardin, 2008) é utilizado por possibilitar o tratamento quantitativo e qualitativo dos dados e ser voltado à análise sistemática de grande quantidade de textos, de modo a proporcionar inferências que possam ser reproduzidas, utilizando o conteúdo manifesto, mas sem desconsiderar o contexto.

O corpus foi codificado em 21 categorias: veículo, data, página, título, autor, menção na capa, editoria/caderno, gênero do texto ${ }^{14}$ (opinativo ou informativo), formato (nota, notícia, reportagem, artigo de opinião, editorial, outros), tamanho, imagem (foto, infográfico, ilustração, misto, outras), tipo de foto (atual ou histórica), quem aparece na imagem, contextualização histórica, fontes, como o golpe de 1964 é nominado, como a ditadura é nominada, expressão de nostalgia, fontes/personagens que expressam nostalgia (reflexiva, restauradora ou retrotopia), quem manifesta nostalgia, menção crítica ou relativizadora da comemoração.

A partir da categorização e codificação, a análise foi realizada com o auxílio do software estatístico SPSS. Os resultados apontam que, das 69 narrativas, 41 foram publicadas pela Folha, o que representa $59 \%$ (Gráfico 1). A maior parte do conteúdo (68\%) não foi mencionada na capa, o que indica que, embora a temática seja relevante, nem sempre mereceu o destaque de constar da primeira página dos jornais.

Proporcionalmente, a Folha garantiu mais destaque à temática ao dedicar mais espaço não apenas no interior das edições, mas também na capa. Na semana analisada, a Folha dedicou espaço em três capas ao tema (Figura 1), já $O$ Globo mencionou os 55 anos do golpe em duas (Figura 2).

Gráfico 1

Quantidade de narrativas publicadas por veículo (\%)

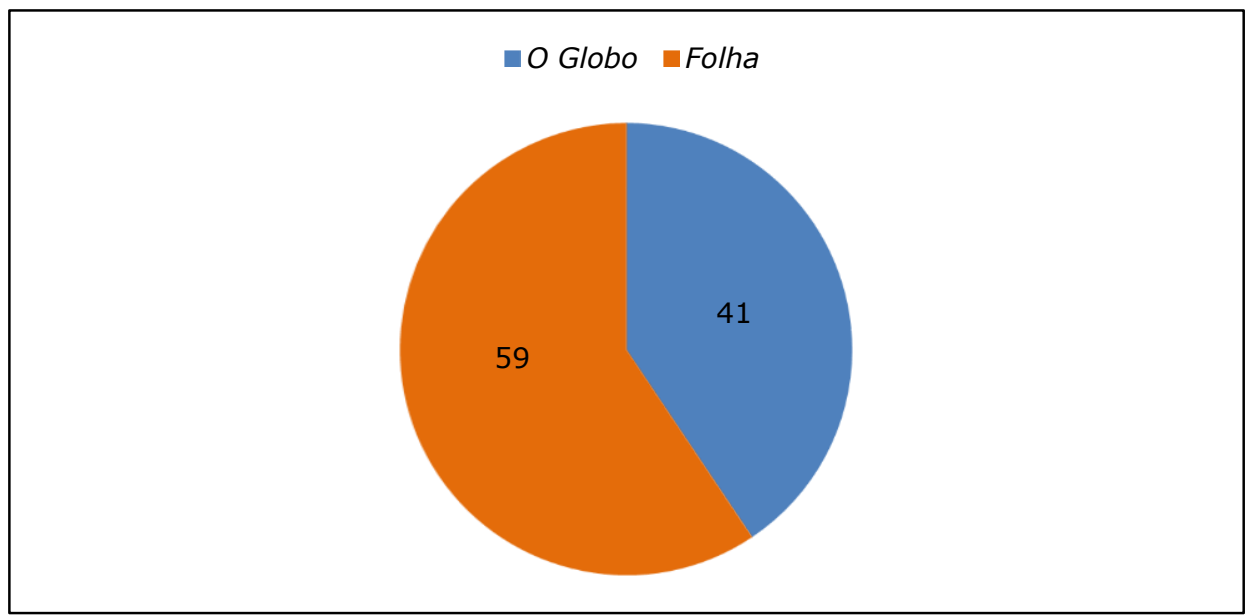

Fonte: Elaboração própria.

\footnotetext{
14 Sabendo das divergências conceituais acerca das classificações dos conteúdos jornalísticos em formatos e gêneros, optamos por usar a classificação de Melo e Assis (2016), mas não consideramos os gêneros diversional, interpretativo e utilitário.
} 
Figura 1

Reprodução das capas da Folha

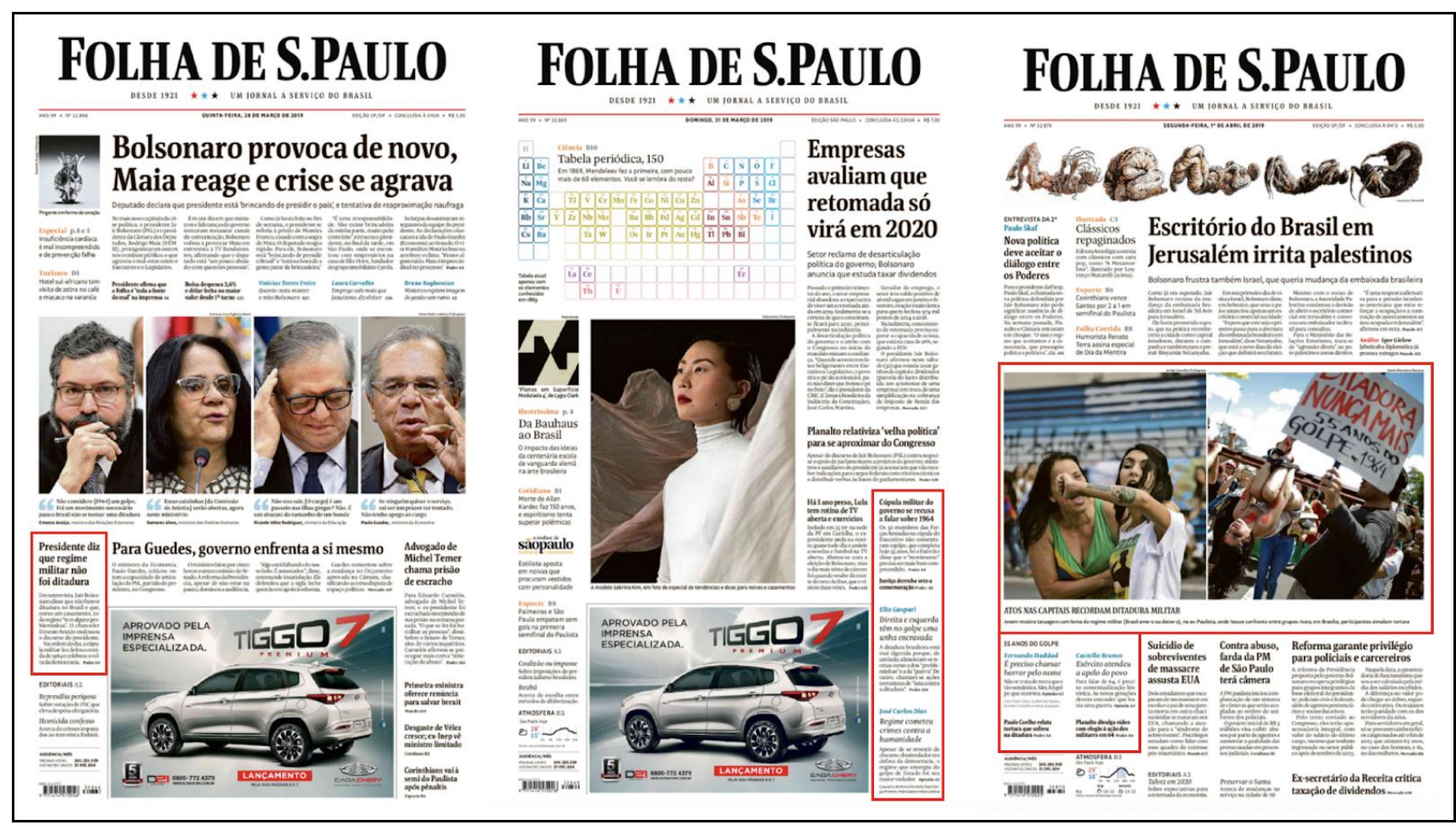

Fonte: Folha de S. Paulo, 28/3/2019, 31/3/2019 e 1/4/2019, na ordem em que aparecem as capas. 
Figura 2

Reprodução das capas de 0 Globo

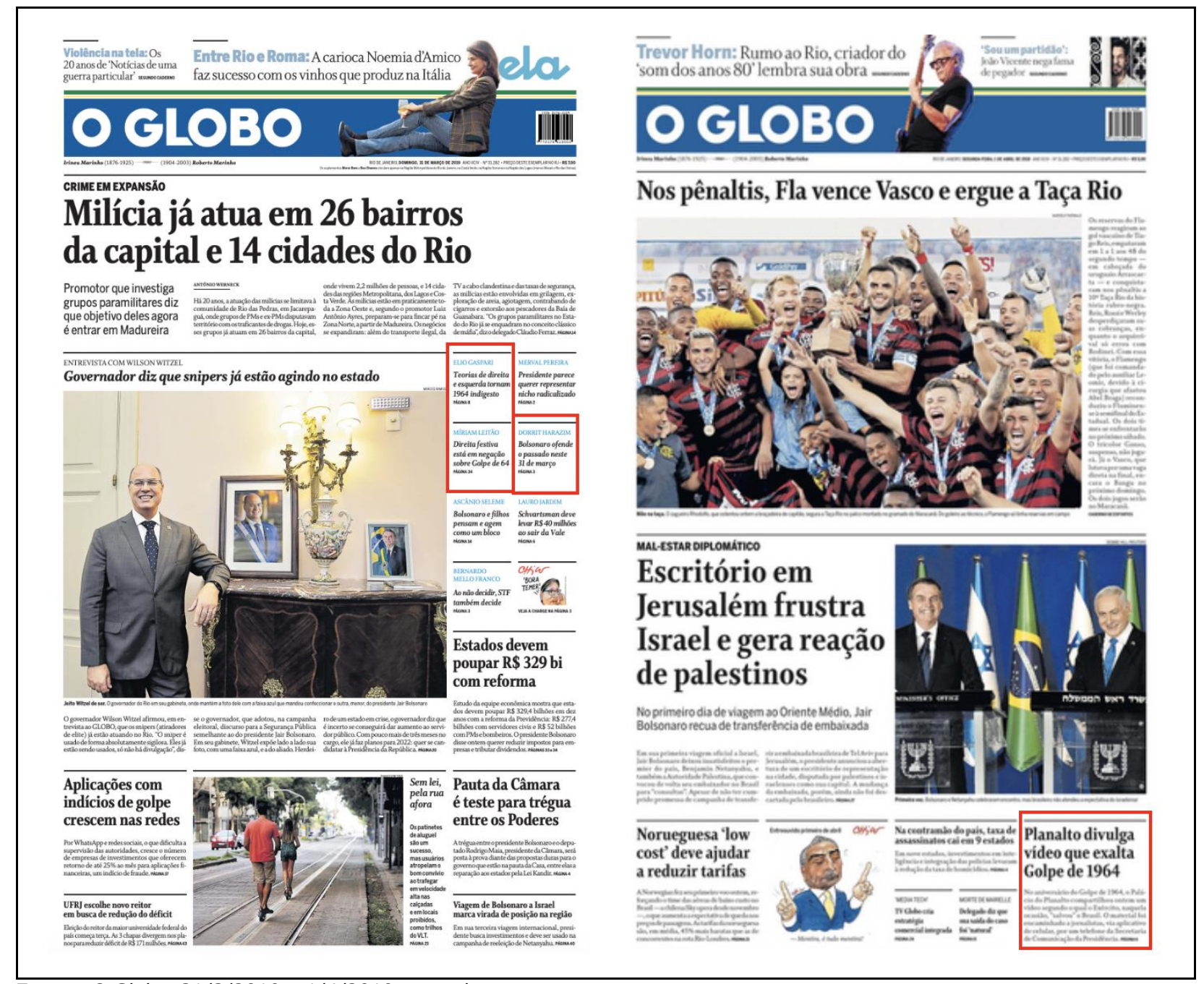

Fonte: $O$ Globo, 31/3/2019 e 1/4/2019, na ordem em que aparecem as capas.

Todavia, em nenhuma das edições a temática foi manchete e, em geral, as chamadas foram dispostas na metade inferior das capas. Notou-se também que nenhuma narrativa ocupou sozinha uma página inteira dos dois jornais, embora o assunto tenha ocupado página inteira - com mais de uma narrativa - em algumas ocasiões, como ocorreu nas páginas A8, de 30 de março, e A6, de $1^{\circ}$ de abril (Figura 3), da Folha. 
Figura 3

Página inteira da Folha dedicada à temática

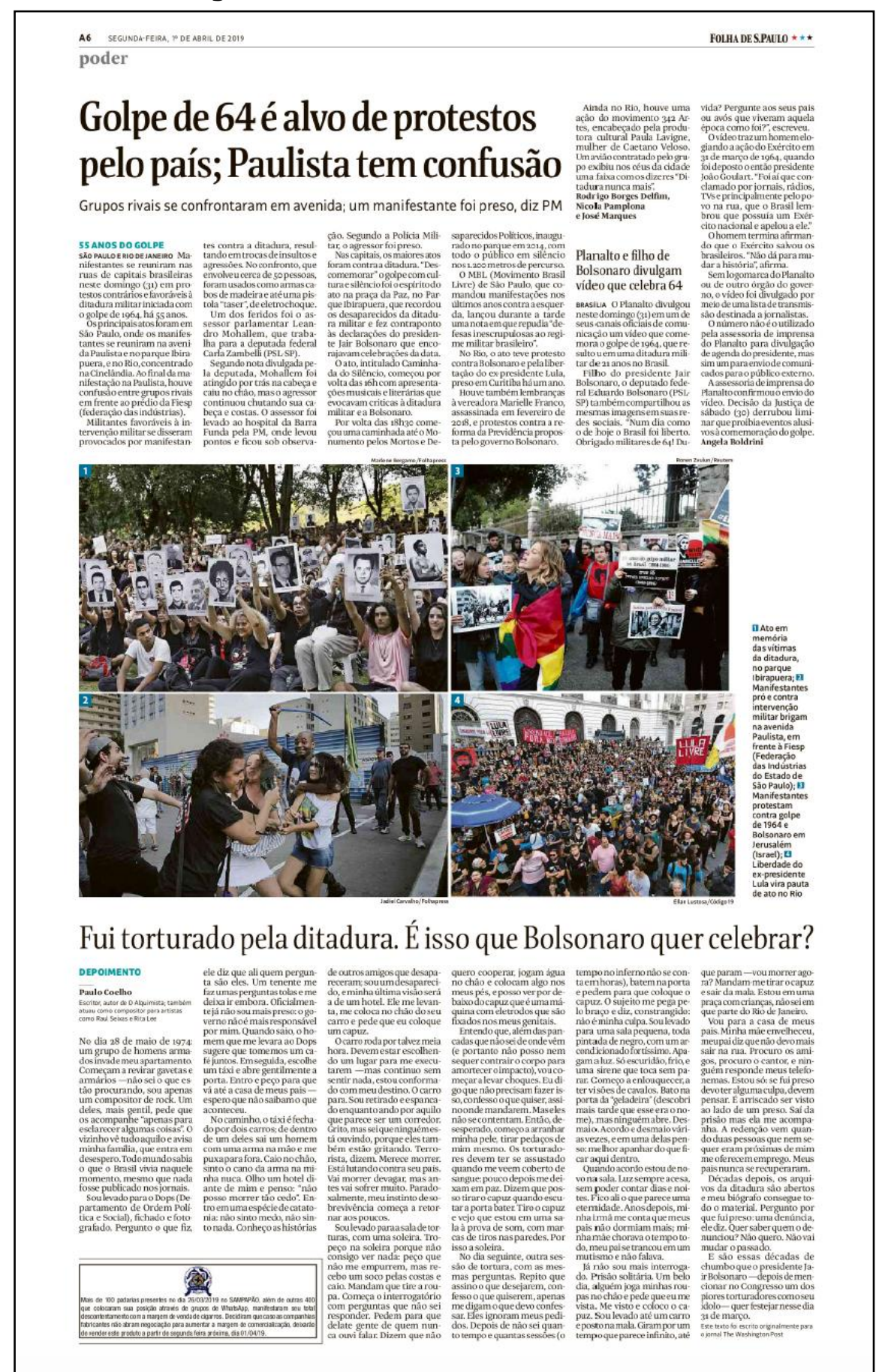

Fonte: Folha de S. Paulo, 1/4/2019. 
O tamanho mais frequente dedicado ao tema por $O$ Globo foi um quarto de página (que ocorreu em oito narrativas). Já na Folha, a maior frequência foi de dois terços de página (nove narrativas) e um terço de página (oito narrativas).

Considerando as editorias, 77\% dos textos foram publicados em "País" (O Globo) e "Poder" (Folha), que se equivalem por tratarem de política, 27\% estavam nas páginas de "Opinião" e o restante, em "Mundo" e "Cotidiano". Isso revela que o tema ainda é tratado predominantemente pelo enfoque político. Cabe ressaltar que, apesar de não terem sido foco desta análise, narrativas sobre a temática também foram publicadas para além do primeiro caderno, como, por exemplo, nos cadernos de cultura.

Em relação aos gêneros jornalísticos, pode-se afirmar que houve um equilíbrio nos dois periódicos, visto que $53 \%$ são narrativas informativas, enquanto $46 \%$ são opinativas (Quadro 1). Mesmo nas seções noticiosas foram encontrados textos de opinião, como os boxes editoriais usados com recorrência por $O$ Globo.

Quadro 1

Quantidade de narrativas por gênero

\begin{tabular}{|l|c|c|c|}
\hline \multirow{2}{*}{ Informativo } & \multirow{3}{*}{37} & Nota & 2 \\
\cline { 3 - 4 } & & Notícia & 22 \\
\cline { 3 - 4 } & & Reportagem & 13 \\
\hline \multirow{3}{*}{ Opinativo } & \multirow{2}{*}{32} & Artigo de opinião & 23 \\
\cline { 3 - 4 } & & Editorial & 3 \\
\cline { 3 - 4 } & & Nota & 4 \\
\cline { 3 - 4 } & & Outros & 2 \\
\hline Total & & & \multicolumn{2}{|c|}{69} \\
\hline
\end{tabular}

Fonte: Elaboração própria.

O modo como o golpe e a ditadura foram nomeados nas narrativas também foi observado. Os resultados demonstram que $81 \%$ delas utilizaram o termo golpe, $4 \%$ usaram apenas 1964 e 14,5\% não mencionaram o termo. Em 68\% do material analisado, a ditadura foi nomeada por termos acusatórios, que remetem ao caráter opressivo do regime - como ditadura, ditadura militar, regime autoritário, autoritarismo etc. - e apenas em uma narrativa foram encontrados somente termos amenizadores - como regime, regime militar, movimento civil-militar. Em 10\% das narrativas, houve ocorrência mista, dos dois tipos de termos, nos casos em que, em geral, os jornalistas precisam usar sinônimos para não repetir a mesma palavra e não se preocupam com o rigor da nomenclatura. Isso revela que os dois veículos seguem a tendência observada por análises anteriores (Sanglard, 2017b) de nomear os episódios respeitando os fatos históricos e utilizando preferencialmente os termos acusatórios.

Em relação à contextualização histórica, 50\% dos textos da Folha e 30\% dos de O Globo fazem uso desse artifício. A Folha, inclusive, criou um chapéu intitulado 55 anos do golpe, marcando cada matéria sobre a temática, incluindo um boxe com uma linha do 
tempo dos acontecimentos pré-1964. Quando as variáveis gênero/formato e presença de contextualização histórica são cruzadas, é notório que tal contextualização ocorre predominantemente nos artigos de opinião, ficando a cargo especialmente dos colunistas desempenhar essa missão, enquanto os demais conteúdos informativos são predominantemente factuais e se enquadram no formato notícia.

Imagens foram usadas em 31 narrativas (45\%), o que demonstra destaque atribuído à quase metade do material em questão. Dessas imagens, há 21 fotos, um infográfico e nove ilustrações (o que inclui duas charges). Todavia, quando se analisa quem estava nas imagens, um aspecto chama a atenção: a presença de militares, do presidente Jair Bolsonaro e de seus ministros. Juntos, eles apareceram em 15 das 31 narrativas com imagem, o que representa $50 \%$. Já fotografias de manifestantes contra a ditadura foram utilizadas em seis narrativas (34\%) e de manifestantes a favor, em quatro (13\%). Isso revela como, ao polemizar sobre a "comemoração" do golpe, o presidente conseguiu de algum modo se colocar no centro do noticiário, que acabou dedicando menos espaço a outros enfoques.

A análise constatou que, de modo geral, os textos não apresentaram sentimento de nostalgia. Isso nos indica que não há um alinhamento dos veículos com a expressão nostálgica, que irá aparecer restrita às fontes e personagens que constam das matérias, não sendo a fala preponderante (cerca de $45 \%$ se manifestam dessa maneira). Dos que assim o fazem, $75 \%$ se valem da retrotopia (Figura 4); quase 19\%, da nostalgia restaurativa (Figura 5); e apenas $6 \%$, da reflexiva. Se juntarmos as manifestações de retrotopia e nostalgia restaurativa, teremos $94 \%$ das declarações ancoradas num tipo de nostalgia que deseja restabelecer o passado (mesmo que ele não tenha acontecido como se imagina) e não apenas lamentar a sua perda. 
Figura 4

Exemplo de retrotopia

\section{A10 TERÇA-FEIRA, 26 DE MARÇO DE 2019 \\ poder \\ Bolsonaro determina 'comemoração devida' dos 55 anos do golpe militar}

Segundo porta-voz, presidente quer que militares lembrem a data, que saiu do calendário com Dilma

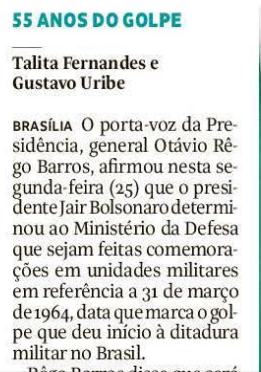

Fonte: Folha de S. Paulo, 26/3/2019, p. A10. $\mp$

0 caminho até o golpe

13.mar.64 Em comício na

Central do Brasil, no Rio

presidente Joäo Goulart

defende nacionalização das refinarias e reforma agrária o que irrita o militares de SP na Marcha da Família

20.mar Em circular, general Castello Branco, chefe do Estado-Maior do Exército, trata as açōes de Jango como 19.mar Milhares vão às ruas ra o 31 de Março de 1964 golpe militar Ele considera que a sociedade reunida e percebendo o perigo que o país estavavivenciando naquele momento juntou-se civise militaresenósconseguimos recuperarerecolocaronossopaís pur rumo que salvo melhor uizo se tudo isso não tivesse juzo, se tudoissonao tivesse ccorido, hoje nos estariamos tendo algum tipo de governo aqui que não seria bom para ninguem, afirmou.

Com a vitória de Bolsonaro, as Forças Armadas avaliam agora reincluir o 31 de Março no calendário oficial do Exército. Procurado pela Folha, o Ministerio da Defesa disse, por meio de sua assessoria de imprensa, quepor enquanto "não dispõe de informações a respeito"

Neste ano, aomenostrês estabelecimentos militares incluíram a efeméride em seus calendários, como o dia da "Revolução Democrática de 1964": a Escola Preparatória

Figura 5

Exemplo de nostalgia restaurativa

Líder do governo, que já criticou 64, agora celebra comemoração da data DIMITRIUS DANTAS Stap Paulo

íder do governo no Con- gresso Nacional, a deputada federal Joice Hasselmann (PSL-SP) celebrou em suas redes sociais a decisão do presidente Jair Bolsonaro de comemorar o golpe mili- tar de 1964. Parlamentares de oposição rebateram a publicação, e a hashtag \#DitaduraNuncaMais tornou-se ontem um dos temas mais comentados do Twitter. Em sua publicação, Joice disse que essa seria a "retomadada narrativa verdadeira de nossa História". Du- rante operíodo, os governos há cinco anos. No dia 24 de militares fecharam o Congresso Nacional, cassaram direitos políticos, perseguirame torturaram adversários políticos e censuraram órgãos de imprensa.

A opinião da deputado, no entanto, sobre o golpe militarde1964 erabemdiferente março de 2014 , a parlamentar postou o seguinte tuíte: " 50 anos do golpe militar: dez razões para não ter saudade da ditadura". A frase er seguida de um link que direcionava os internautas para uma página do site "blogda joice.com", retirada doar.
A publicação desta semana de Joice sobre 1964 re. percutiu na internet. O dementa (PT-RS) afirmou na rede que a ordem dada para que as Forças Armadas celebrem o golpe é mais um erro de Bolsonaro: putado federal Paulo Pi-

Fonte: O Globo, 27/3/2019, p. 10. 
Quadro 2

Formatos $X$ ocorrência de expressão de nostalgia

\begin{tabular}{|l|c|c|c|c|c|}
\hline Formato & Reflexiva & Restaurativa & Retrotopia & Não há & Total \\
\hline Nota & 1 & 1 & 1 & 3 & 6 \\
\hline Notícia & 0 & 2 & 11 & 9 & 22 \\
\hline Reportagem & 0 & 2 & 4 & 7 & 13 \\
\hline Artigo Opinião & 1 & 1 & 7 & 14 & 23 \\
\hline Editorial & 0 & 0 & 1 & 2 & 3 \\
\hline Outros & 0 & 0 & 0 & 2 & 2 \\
\hline Total & 2 & 6 & 24 & 37 & 69 \\
\hline
\end{tabular}

Fonte: Elaboração própria.

Também é nas notícias que a retrotopia aparece mais frequentemente, com um percentual de $45 \%$. Embora haja mais textos jornalísticos sem expressão de nostalgia, quando observados os formatos, vamos identificar que há mais notícias com expressão de nostalgia, seja de que tipo for (Quadro 2).

Essa percepção torna-se ainda mais delicada quando cruzamos as categorias de contextualização histórica com a expressão de nostalgia pelas fontes. Das 24 narrativas em que os personagens demonstraram retrotopia, apenas 9 tinham contextualização histórica, ou seja, $62 \%$ dessas manifestações foram feitas sem que o texto se preocupasse em apresentar o contexto do golpe. É um modus operandi semelhante ao encontrado quando cruzamos a existência de contextualização com a menção crítica ou relativizada à proposta de comemoração do governo.

Quadro 3

Contextualização histórica $X$ menção crítica à proposta de comemoração

\begin{tabular}{|l|c|c|c|c|c|}
\hline $\begin{array}{l}\text { Contextualização } \\
\text { histórica? }\end{array}$ & $\begin{array}{c}\text { Apenas cita } \\
\text { informação }\end{array}$ & $\begin{array}{c}\text { Critica de } \\
\text { modo raso }\end{array}$ & $\begin{array}{c}\text { Critica de } \\
\text { modo } \\
\text { contextual }\end{array}$ & $\begin{array}{c}\text { Não se } \\
\text { aplica }\end{array}$ & Total \\
\hline Não & 12 & 14 & 6 & 4 & 36 \\
\hline Sim & 13 & 0 & 14 & 6 & 33 \\
\hline Total & 25 & 14 & 20 & 10 & 69 \\
\hline
\end{tabular}

Fonte: Elaboração própria.

Por outro lado, mesmo sem a contextualização histórica com relação ao golpe de 1964, quando cotejamos as categorias "expressão de nostalgia pelas fontes" e "menção crítica ou relativização da proposta de comemoração", o resultado aponta para um esforço dos veículos em criticar a proposta e contextualizar a questão. Assim, 54\% das manifestações de retrotopia por parte das fontes contam com textos jornalísticos mais críticos quanto à ideia de comemoração dos 55 anos do golpe.

Por fim, parece-nos relevante destacar que, numa comparação entre os posicionamentos dos veículos em relação à comemoração dos 55 anos do golpe, a Folha adota postura mais crítica que O Globo, ainda que, em 39\% das narrativas, não haja menção à proposta de comemoração e, portanto, não tenha havido crítica. Mesmo 
considerando que 34\% das matérias do jornal paulistano apenas apresentam a informação, um percentual bem próximo, quase $32 \%$, critica a proposta e contextualiza a questão. Em O Globo, a proporção é diferente. Cerca de $39 \%$ se limitam a mencionar o fato, seguidos de aproximadamente $36 \%$ que criticam a proposta de modo raso e $25 \%$ que criticam a proposta fazendo contextualização.

\section{Análise qualitativa do corpus}

Na cobertura dedicada por $O$ Globo à data, Bolsonaro é o principal personagem. As narrativas publicadas são, em grande parte, impulsionadas por suas declarações - de que o 31 de março deveria ser comemorado e de que ele não considerava ter existido ditadura - e por críticas feitas a elas por diversos personagens, sejam autores de colunas, sejam outras fontes, como o Ministério Público Federal (MPF) ou o presidente chileno Sebastian Piñera.

Ainda que Bolsonaro seja o principal personagem dos textos jornalísticos da Folha, assim como acontece em $O$ Globo, bem como o agente que estabelece essa agenda no noticiário, identificamos algumas diferenças no trato da questão. A primeira delas diz respeito ao volume de notícias, reportagens e artigos de opinião. Enquanto $O$ Globo publicou 28 textos, a Folha editou 41.

No que diz respeito à contextualização histórica, também houve diferenças. No jornal carioca, tais contextualizações são passageiras e ressaltam pontualmente aspectos ditatoriais institucionalizados depois de 1964, como cassações, perseguições, tortura, censura e prisões políticas. Já na Folha, essa contextualização é feita de modo mais consistente, incluindo linhas do tempo do golpe, lista de perguntas e respostas sobre o golpe e suas consequências para o país. A Folha também publica matérias contextuais sobre temas específicos da ditadura, como o Serviço Nacional de Informações (SNI), análise de livros didáticos sobre divergências na forma como aparece o suporte civil ao golpe ou, ainda, sobre expectativas da CIA com relação ao desfecho dos governos militares após o golpe.

Outro ponto a se destacar é o modo como são apresentados tons distintos no governo sobre o 31 de março. Em O Globo, o ministro da Defesa, Azevedo Lima, é apontado como uma voz moderada no governo, destoando do presidente por falar em "transição para a democracia" e por dizer que "comemoração" não é o termo mais adequado, e sim lembrança, por se tratar de uma "data histórica". A fala do ministro permite perceber um conflito entre nostalgia e memória. Na mesma narrativa, foi consultado o vice-presidente Hamilton Mourão, que tentou pacificar a ocorrência das comemorações afirmando que a ordem do dia seria conciliadora.

A Folha, da mesma forma, ressalta as disputas dentro do governo entre a ala militar e outros grupos, e como a ordem de Bolsonaro, de que o golpe deveria ser comemorado, teria sido criticada mesmo por seus apoiadores. O jornal também destaca a oposição à comemoração da ditadura por entidades e personagens (como a Defensoria Pública da 
União e diplomatas) e críticas diversas a Bolsonaro. A Folha dá espaço à cobertura de protestos civis contra a comemoração, ao contrário de $O$ Globo.

Embora tanto em um quanto em outro jornal haja predominância das vozes oficiais como fontes, são apresentadas vozes dissidentes, em notas, textos de opinião, análises de repórteres que aparecem como analistas ou críticos do período da ditadura e da decisão de Bolsonaro de celebrá-la. Ainda assim, nos dois jornais estão ausentes ou são minoritárias as vozes dos diretamente atingidos pela repressão. A exceção é um depoimento de Paulo Coelho (2019) sobre a tortura a que foi submetido.

Embora a nostalgia do presidente seja repreendida em $O$ Globo, o jornal trata o assunto de forma econômica. Ele aparece exclusivamente no formato de críticas a medidas de personagens do governo (Bolsonaro, Damares Alves). Ou seja, ainda que criticadas, as vozes conservadoras e oficiais se sobrepõem à alternativa que seria evidente: não há narrativas com o outro lado diretamente atingido, como perseguidos e presos políticos durante a ditadura.

Na Folha, há matérias com tom mais crítico se comparadas às de $O$ Globo, e a temática aparece em um editorial principal do jornal em que Bolsonaro é criticado especialmente por estimular a polarização e não o consenso - é, portanto, acusado (ali e em artigos de opinião) de agir de modo incompatível com o cargo que ocupa. O Globo não dedica um editorial principal a isso, embora tenha publicado alguns boxes editoriais em meio a matérias sobre o assunto.

O enquadramento privilegiado pelo jornal carioca é o de conflito, envolvendo especialmente a polêmica dentro da disputa pela memória: se a data deveria ou não ser comemorada, se houve ou não ditadura. Essa disputa inclusive é explicitada numa declaração de Bolsonaro, após ser confrontado por sua determinação de comemoração dos 55 anos do golpe, ao dizer que a intenção do governo era "rememorar" a data, e não comemorá-la. Chama a atenção que, após o presidente mudar o seu discurso, O Globo passe a adotar o termo "rememoração". Ainda que as aspas marquem o tom crítico, a repetição do termo ameniza o episódio e dá espaço especialmente à versão de Bolsonaro. A Folha foca nas disputas dentro do próprio governo e produz uma cobertura mais ampla, com contextualizações, mais crítica e com mais destaques sobre aspectos da ditadura que se seguiu ao golpe.

De modo geral, chamar o que aconteceu em 1964 de golpe ou o regime instaurado de ditadura não são mais as questões em disputa: tornaram-se consenso em $O$ Globo e na Folha. Em ambos os jornais, sobressaem as disputas pela memória dentro do próprio governo. Bolsonaro desponta como radical, sendo a representação da visão dos próprios militares sobre a data, eventualmente, construída como cautelosa. Embora as vozes oficiais não sejam as únicas a aparecer, como já dissemos, destacamos que a voz dos diretamente atingidos é silenciada.

Tais condições demonstram que não há uma memória coletiva sobre a ditadura, mas sim memórias em disputa. Apesar de majoritariamente haver algum consenso social de que os regimes autoritários ferem os direitos fundamentais dos cidadãos, a demora em 
desenvolver políticas de memória e ações mais efetivas em prol da justiça de transição no Brasil abriu campo para que constantemente a memória pública mais progressista sobre o período seja confrontada, inclusive por agentes públicos. Apesar de o relatório da CNV ser o documento público e oficial produzido pelo Estado - com participação da sociedade e sustentado em depoimentos de testemunhas, pesquisas e documentos -, ainda não é possível considerar que tal avanço tenha sido impactante para a memória pública da ditadura. Obviamente contribui para o processo de tentativa de estabelecer tal memória, mas revela que foi insuficiente.

\section{Considerações finais}

Este artigo buscou analisar as narrativas jornalísticas publicadas na ocasião dos 55 anos do golpe civil-militar de 1964 em dois dos principais jornais brasileiros, O Globo e Folha de S. Paulo, com o objetivo de verificar como esses dois veículos da grande imprensa abordam a data a partir, especialmente, do posicionamento do governo. Partimos da hipótese de que esses discursos estão impregnados do sentimento da nostalgia, diferindo, nesse sentido, das declarações consideradas pela mídia na cobertura dessa efeméride cinco anos antes. Com base no referencial teórico sobre memória e nostalgia, pretendeu-se entender como a ditadura é trazida ao presente, ressignificada e até mesmo considerada como opção viável a partir do discurso de autoridades políticas. Para isso, utilizamos como método a análise de conteúdo (Krippendorff, 1990; Bardin, 2008) aplicada às narrativas jornalísticas noticiadas pelos dois veículos no período entre 26 de março e 2 de abril de 2019.

Ainda que percebamos, em vários dos textos jornalísticos analisados neste artigo, a presença da nostalgia reflexiva ou restauradora, é como retrotopia que ela se manifestou de modo mais intenso - presente em $45 \%$ das notícias. Identificamos nas falas de diversos atores políticos - como Bolsonaro, seu filho Flávio e alguns ministros - esse desejo por um passado que se imagina utópico, que não aconteceu de fato, mas que seria, no imaginário nostálgico, fundamental para a formação de um presente positivo. É esse, por exemplo, o tom que encontramos em várias declarações que sentenciam que o golpe teria sido o responsável por livrar o Brasil de uma ditadura ou por impedir que o país se aproximasse do modelo da Venezuela.

Nessa perspectiva, a retrotopia avança para além da "rememoração", para usar o termo que se fixou na cobertura, após Bolsonaro ajustar sua declaração inicial de determinação para a comemoração dos 55 anos do golpe civil-militar. O perigo da retrotopia consiste justamente no potencial que ela adquire de não se restringir a um sentimento nostálgico, mas de pretender remodelar a memória coletiva e se estabelecer como a verdade histórica.

As declarações retrotópicas que foram objeto desta análise apontam para essa intenção de "reescrever a história", para que ela atenda às posições político-ideológicas do grupo que está no poder e também do grupo que se sente derrotado pelo fim da ditadura. 
O que parece acalentador, nesse cenário, é que os dois principais veículos diários impressos do país não estão embalados no mesmo sentimento retrotópico, ainda que percebamos a falta de pluralidade de vozes nas narrativas e as diferenças no modo de tratamento do fato entre a Folha de S. Paulo e O Globo.

Seja por meio da homenagem a agentes de Estado que atuaram na repressão e do incentivo à comemoração das violações dos direitos humanos representadas pelo golpe e pela ditadura, seja pela circulação de informações historicamente não comprovadas, o que se vê atualmente é um processo que envolve não apenas uma disputa de sentidos ou de narrativas, mas também uma política de ataque às instituições democráticas e à pesquisa no campo das humanidades e das ciências sociais, como forma de sustentar versões fantasiosas dos processos históricos. É justamente a identificação desses fatores que torna a pesquisa sobre as narrativas contemporâneas acerca dos aniversários do golpe de 1964 e, consequentemente, da ditadura ainda mais relevante.

\section{Referências bibliográficas}

APPADURAI, A. Modernity at large: cultural dimensions of globalization. Minneapolis: University of Minnesota Press, 2011.

BARdin, L. Análise de conteúdo. Lisboa: Edições 70, 2008.

BAuman, Z. Retrotopia. Rio de Janeiro: Zahar Editores, e-book (kindle), 2017.

Boym, S. The future of nostalgia. New York: Basic Books, 2001.

Coelho, P. "Fui torturado pela ditadura. É isso que Bolsonaro quer celebrar?". Folha de S. Paulo, São Paulo, $1^{\circ}$ de abril de 2019. Poder, p. A.6.

DIAS, A. B. O presente da memória: usos do passado e as (re)construções de identidade da Folha de S. Paulo, entre o "golpe de 1964" e a "ditabranda". Jundiaí: Paco Editorial, 2014.

ÉBOLI, E. "Após ordem de silêncio, general fica à vontade entre comando do exército". O Globo, p. 9, 2 abr. 2011.

FERNANDES, T.; URIBE, G. "Bolsonaro determinou 'comemorações devidas' do golpe de 1964, diz porta-voz" (online). Folha de S. Paulo, 25 mar. 2019. Disponível em:

<https://www1.folha.uol.com.br/poder/2019/03/bolsonaro-determinou-comemoracoes-devidas-dogolpe-de-1964-diz-porta-voz.shtml>. Acesso em: 15 jan. 2020.

FICo, C. O golpe de 1964: momentos decisivos. Rio de Janeiro: Editora FGV, 2014.

Folha dE S. PAUlo. "Empresário diz que bancou vídeo sobre golpe de 64 divulgado pelo Planalto", 2 abr. 2019. Disponível em: <https://www1.folha.uol.com.br/poder/2019/04/empresario-diz-quebancou-video-sobre-golpe-de-64-divulgado-pelo-planalto.shtml>. Acesso em: 8 jun. 2021.

G1. "Presidente Bolsonaro manda quartéis celebrarem o 31 de março" (online), 25 mar. $2019 a$. Disponível em: <https://g1.globo.com/jornal-nacional/noticia/2019/03/25/presidente-bolsonaromanda-quarteis-celebrarem-o-31-de-marco.ghtml>. Acesso em: 19 fev. 2020.

"Vídeo que nega o golpe de 1964 é distribuído em canal de comunicação do Planalto" (online), 31 mar. 2019b. Disponível em: <https://g1.globo.com/politica/noticia/2019/03/31/videoque-nega-o-golpe-de-1964-e-distribuido-em-canal-de-comunicacao-do-planalto.ghtml>. Acesso em: 15 jan. 2020. 
GAGLIARDI, J. "Mediando a 'revolução': a narrativa de $O$ Globo sobre os aniversários do golpe durante o regime militar (1965-1984)". Lumina, vol. 8, no 2, p. 1-35, 2014.

GAGLIARDI, J. "Um projeto de poder por vias não democráticas: O Globo e a narrativa do lulopetismo". Programa de Pós-Graduação em Comunicação, Instituto de Artes e Comunicação Social: Tese de Doutorado. Universidade Federal Fluminense, Niterói, 2018.

Gagliardi, J.; SANGLARD, F. "Traumatic past: $O$ Globo newspaper coverage on the Brazilian military dictatorship". In: Global Fusion, Texas A\&M University, College Station, Texas, 23-25 out. 2015.

Galtung, J.; Ruge, M. A estrutura do noticiário estrangeiro - A apresentação das crises do Congo, Cuba e Chipre em jornais estrangeiros. In: TRAQUINA, N. (org.). Jornalismo: questões, teorias e "estórias". Florianópolis: Insular, 2016.

HalbWachs, M. A memória coletiva. São Paulo: Vértice, 1990.

Jelin, E. Los trabajos de la memoria. Madri: Siglo XXI de España Editores, 2002.

. La lucha por el pasado: cómo construimos la memoria social. Buenos Aires: Siglo

Veintiuno Editores, 2017.

KRIPPENDORFF, K. Metodologia de análisis de contenido. Barcelona: Paidós, 1990.

MACEDO, C. S. "Tudo sobre a Ditadura Militar e, sobretudo, a ditadura militar: memória e esquecimento no jornal Folha de S. Paulo". Programa de Pós-Graduação em Comunicação:

Dissertação de Mestrado, Faculdade de Filosofia e Ciências Humanas. Universidade Federal de Minas Gerais, Belo Horizonte, 2018.

MALTCHIK, R. "Exército manda que general se cale sobre 64". O Globo, p. 10, 1 abr. 2011.

MAZUi, G; BARBIERI, L. F. "Bolsonaro diz que texto a ser lido nos quartéis não tem objetivo de 'comemorar' golpe de 1964" (online). G1, 28 mar. 2019. Disponível em:

<https://g1.globo.com/politica/noticia/2019/03/28/bolsonaro-diz-que-ordem-do-dia-nos-quarteisnao-tem-objetivo-de-comemorar-golpe-de-1964.ghtml>. Acesso em: 15 jan. 2019.

Melo, J. M.; Assis, F. "Gêneros e formatos jornalísticos: um modelo classificatório". Intercom RBCC, São Paulo, vol. 39, no 1, p 39-56, jan.-abr. 2016.

Niemeyer, K. O poder da nostalgia. In: SANTA Cruz; L.; Ferraz, T. (orgs.). Nostalgias e mídia: no caleidoscópio do tempo. Rio de Janeiro: E-papers, 2018.

OliveirA, V. V. "Mídia, memória pública e Comissão Nacional da Verdade no Brasil". Programa de Pós-Graduação em Comunicação Social: Tese de Doutorado. Universidade Federal de Minas Gerais, Faculdade de Filosofia e Ciências Humanas, Belo Horizonte, 2017.

O GLOBO. "Cinco anos fecundos para o Brasil", 1 abr., p. 1, 1969.

Pollak, M. "Memória, esquecimento, silêncio". Estudos Históricos, Rio de Janeiro, vol. 2, no 3, p. 3$25,1989$. 212, 1992.

"Memória e identidade social". Estudos Históricos, Rio de Janeiro, vol. 5, no 10, p. 200-

RICfur, P. A memória, a história, o esquecimento. Campinas: Editora Unicamp, 2007.

SANGLARD, F. N. "Verdades possíveis: o jornalismo brasileiro e as narrativas sobre a ditadura durante o funcionamento da Comissão Nacional da Verdade". Programa de Pós-Graduação em Comunicação: 
Tese de Doutorado, Faculdade de Comunicação Social, Universidade do Estado do Rio de Janeiro. Rio de Janeiro, 2017a.

SANGLARD, F. N. "Jornalismo e ditadura: análise da cobertura midiática durante os trabalhos da Comissão Nacional da Verdade". Anais do VII Congresso da Associação Brasileira de Pesquisadores em Comunicação e Política (VII Compolítica), Universidade Federal do Rio Grande do Sul (UFRGS), 10-12 maio 2017b. Disponível em: <http://www.compolitica.org/home/wpcontent/uploads/2017/06/SANGLARD_JORNALISMO-E-DITADURA.pdf>. Acesso em: 15 jan. 2020.

Santa Cruz; L.; Ferraz, T. A propósito da nostalgia. In: Santa Cruz; L.; Ferraz, T. (orgs). Nostalgias e mídia: no caleidoscópio do tempo. Rio de Janeiro: E-papers, 2018.

SCHUDSON, M. A política da forma narrativa: a emergência das convenções noticiosas na imprensa e na televisão. In: TRAQUiNA, N. (org.). Jornalismo: questões, teorias e "estórias". Lisboa: Editora Vega, p. 279-293, 1993.

SchwarCz, L. M. Sobre o autoritarismo brasileiro. Rio de Janeiro: Companhia das Letras, 2019.

TRAQUinA, N. Teorias do jornalismo: por que as notícias são como são. Vol. 12. Florianópolis: Insular, 2005.

. Teorias do jornalismo: a tribo jornalística, uma comunidade interpretativa transnacional. Vol. 2. $2^{\circ}$ ed. Florianópolis: Insular, 2008.

TUCHMAN, G. A objectividade como ritual estratégico: uma análise das noções de objectividade dos jornalistas. In: TRAQUiNA, N. (org.). Jornalismo: questões, teorias e "estórias". Lisboa: Editora Vega, 1993.

Wolf, M. Teorias da comunicação. $5^{\circ}$ ed. Editorial Presença: Lisboa, 1999.

\begin{abstract}
Rememoration and retrotopia: Folha de S. Paulo and O Globo coverages of the 55th anniversary of the 1964 coup d'État

This article analyzes how two of the main vehicles of the great Brazilian press - O Globo and Folha de S. Paulo - addressed the 55th anniversary of the 1964 civil-military coup. It starts with a theoretical framework on memory and nostalgia and the analysis of content applied to journalistic narratives published between March 26 and April 2, 2019 to answer the following questions: Was there nostalgia in the narratives of political actors in relation to the dictatorship? How did journalistic narratives address this feeling and take a position on it? The results indicate the existence of disputed memories in relation to the dictatorship, which is evident in the speech of several actors. Although the vehicles do not align with the nostalgic sentiment, retrotopia was identified in $45 \%$ of the sources' statements and President Jair Bolsonaro was the main character of the news.
\end{abstract}

Keywords: nostalgia; 1964 coup d'État; journalism; O Globo; Folha de S. Paulo

\title{
Resumen
}

Rememoración y retrotopia: cobertura de Folha de S. Paulo y O Globo del $55^{\circ}$ aniversario del golpe de 1964

Este artículo analiza cómo dos de los principales vehículos de la gran prensa brasileña, $O$ Globo y Folha de S. Paulo, abordaron el 55 aniversario del golpe civil-militar de 1964. Tiene la intención de entender cómo, en un estado que dice ser democrático, la dictadura es llevada al presente, reformulada e incluso considerada como una opción viable desde el discurso del gobierno federal y sus representantes y qué papel asume el periodismo tradicional a este respecto. Partimos de un marco teórico sobre memoria y nostalgia y aplicamos el método de análisis de contenido a las narrativas 
periodísticas publicadas por los dos medios en el período comprendido entre el 26 de marzo y el 2 de abril de 2019 para responder a las siguientes preguntas: Hubo nostalgia en las narrativas de los actores políticos con respecto a la dictadura? ¿Cómo abordaron las narrativas periodísticas este sentimiento? ¿Cómo se posicionó la producción periodística en esto?

Palabras clave: nostalgia; Golpe de 1964; periodismo; O Globo; Folha de S. Paulo

\section{Résumé}

Memoires et rétrotopie: Couverture de Folha de S. Paulo et O Globo du 55e anniversaire du coup d'État de 1964

Cet article analyse comment deux des principaux véhicules de la grande presse brésilienne - $O$ Globo et Folha de S. Paulo - ont abordé le 55e anniversaire du coup d'État civilo-militaire de 1964. Il commence par un cadre théorique sur la mémoire et la nostalgie et l'analyse de contenu appliqué aux récits journalistiques publiés entre le 26 mars et le 2 avril 2019 pour répondre aux questions suivantes: Y a-t-il eu de la nostalgie dans les récits d'acteurs politiques par rapport à la dictature? Comment les récits journalistiques ont-ils abordé ce sentiment et pris position à ce sujet? Les résultats indiquent l'existence de memoires contestés par rapport à la dictature, ce qui est évident dans le discours de plusieurs acteurs. Bien que les véhicules ne correspondent pas au sentiment nostalgique, la rétrotopie a été identifiée dans $45 \%$ des déclarations des sources et le président Jair Bolsonaro était le personnage principal des textes journalistiques.

Mots-clés: nostalgie; Coup d'État de 1964; journalisme; O Globo; Folha de S. Paulo

Artigo submetido à publicação em 15 de junho de 2020. Versão final aprovada em 5 de fevereiro de 2021.

Opinião Pública adota a licença Creative Commons CC-BY. OPINIÄO PÜBLICA

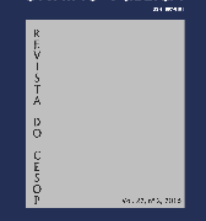

